\title{
Vegetation development and the condition of natural regeneration after coal mine reclamation in East Kalimantan, Indonesia
}

T Yunanto Ministry of Energy and Mineral Resources, Republic of Indonesia

R Mitlöhner Goettingen University, Germany

R Bürger-Arndt Goettingen University, Germany

\begin{abstract}
As one of the most important mining commodities, coal has been massively exploited as a source of income for the national economy. In general, a coal mining company conducts mining operations in forest areas by employing an open pit mining method. The implementation of an open pit mining method can cause negative environmental impacts, i.e. changes to the forest landscape, reduction in soil quality, reduced biodiversity for both flora and fauna etc. To overcome and mitigate devastating environmental impacts resulting from mining operations in the forest area, land reclamation should be conducted on the ex-mine area. In Indonesia there is still little knowledge on vegetation development and the natural regeneration in mine reclamation areas. Therefore, it is important to understand the stand structure, floristic composition and whether or not the reclaimed mining area can create a good environment for natural regeneration and redevelop into a selfsustaining forest ecosystem. The research was carried out at six stand types, namely five differences age of reclamation areas and secondary natural forest for the comparison. A vegetation inventory was conducted at each stand type covering an area of \pm 1 ha (total \pm 6 ha) using a circular plot. Result shows that the stand structure (diameter at breast height, total height, density and basal area) between the reclamation areas were different. Moreover, the reclamation areas with an age greater than four years demonstrate higher mean values for different aspects of stand structure than the secondary natural forest. Conversely, in terms of floristic composition such as species and diversity index, secondary natural forest still had higher mean values than all ages reclamation areas. The older reclamation ages tend to have a higher number of species and diversity index than the younger ages. Natural regenerations were occurred from the first year of reclamation. In general, based on the regression analysis the number of naturally grown species in the seedling, sapling and tree stages tend to increase alongside the rise in reclamation age. These results conclude that the reclamation activities in ex-mine areas have succeeded to create favourable environmental conditions for natural regeneration.
\end{abstract}

Keywords: coal, mine reclamation, stand structure, floristic composition, natural regeneration

\section{$1 \quad$ Introduction}

As a country with one of the highest amount of energy and mineral resources in the world, Indonesia relies on the exploitation of mining commodities for its national economy. One of the most important mining commodities for its national income is coal. It is undeniable that the exploration and exploitation of energy and mineral resources will bring about environmental damage (Environmental Law Alliance Worldwide 2010). Mining activities carried out within a forest area will have a major impact on the environment from both a vegetation and soil perspective. The impact of mining activities results in the reduction or total loss of biodiversity (Lloyd et al. 2002), the modification of soil conditions (Subowo 2011) and deep and wide holes (Doupé \& Lymbery 2005).

To reduce environmental harm caused by mining activities during the exploration or exploitation phase, the former mining area must carry out the process of land reclamation. The reclamation process in forest areas 
is not only aimed at improving unstable land conditions and reducing soil erosion, but it also aims, in the long-term, to improve forest ecosystems regarding microclimate, wildlife biodiversity, natural vegetation biodiversity and soil conditions (Heras et al. 2008).

Succession is the process of natural change in the species composition of plant or animal, or species association, in an area over time. In association with forest succession, succession means the process of replacing tree species or tree associations (Martin \& Gower 1996). In general, succession is divided into two types, namely primary succession and secondary succession. The difference between these two types of succession is the initial condition of the succession habitat. Primary succession is caused by disturbances such as volcanoes, earthquakes, landslides, floods or hot-burning fires, whereby the disturbances result in the loss of soil and organisms from the site, leaving only empty rocks, silt, gravel or sand. This is said to be a "primer" because soil is a key aspect of the plant's life. Meanwhile, secondary succession is caused by disturbances such as windstorms, avalanches, insect outbreaks, logging, bulldozers or fire that leaves the soil intact. Seeds, spores and plant roots are still present. Areas beginning with a secondary succession process will usually reach the next stage faster than the primary succession process. The number and types of plants that survive often depends on the depth and gradation of soil. The mining operations in the forest area lead to the complete clearing of plants and soils. Mine reclamation is one form of the primary succession process, as it aims to restore the forest to its original state over a very long time. However, it is necessary replant tree species in the ex-mining area in order to accelerate forest succession caused by mining operations.

This study aims to understand the vegetation development of the reclamation of an ex-mining area that used an open pit mining method. In particular, the objectives of this study are:

- Compare the vegetation structure between the reclamation areas and the secondary natural forest.

- Compare the floristic composition between the reclamation areas and the secondary natural forest.

- Measure the natural regeneration occurred in the reclamation area.

\section{Methodology}

\subsection{Research area}

The research was conducted at the coal mining company PT Mahakam Sumber Jaya (PT MSJ), which is located in the Kutai Kartanegara Regency and Samarinda City, East Kalimantan Province, Indonesia in July to October 2016. The company has a total area of approximately 20,380 ha, which is divided into five blocks (Block A, B, C, D and E) consisting of forest and non-forest areas. In general, there are $16,240.22$ ha $(79.69 \%)$ of forest area and 4,139 ha $(20.31 \%)$ of non-forest area in PT MSJ. The forest area is owned by the plantation forest company of PT Sumalindo Hutani Jaya whereas the communities hold the ownership of non-forest area. According to precipitation data between 2001 and 2010, rainfall ranged from 1,787 to 2,634 mm p.a. The highest amount of rainfall occurred in March $(268 \mathrm{~mm})$ and the lowest amount was recorded in August $(95 \mathrm{~mm})$. In general, the land cover of the research area is dominated by shrubs or pioneer plants covering 18,142 ha or about $89 \%$ of the total area of mining concession.

Before being opened the existing vegetation in Block $A$ was dominated by pioneer tree species, but there were also several species of herbaceous swamps and agricultural crops existing in the block. The vegetation conditions in Block B were also dominated by agricultural crops and pioneer trees. Some of the agricultural crops found in Block B, such as banana (Musa spp.), pecan (Aleurites moluccana), chocolate (Theobroma cacao), were grown by farmers. Based on field observations, the general condition of vegetation in Block $\mathrm{C}$ is currently undergoing a reclamation process dominated by various pioneer tree species such as Paraserianthes falcataria, Senna siamea, Enterolobium cyclocarpum, Samanea saman etc. The condition of vegetation in Block $D$ consisted of woody plants which indicate a secondary natural forest. Based on the vegetation inventory of environmental impact assessment (EIA) document preparation, the woody plant species found in Block D are Vernonia arborea, Macaranga tanarius, Macaranga triloba etc. Akin to the 
existing vegetation conditions in Block D, the vegetation conditions in Block $\mathrm{E}$ also consisted of several woody plants from the secondary natural forest.

PT MSJ has been carrying out the reclamation process since 2005 (Table 1) with a planting space $4 \mathrm{~m} \times 4 \mathrm{~m}$. The reclamation process was carried out in the five mining blocks, which were divided into several small blocks. The tree species planted were fast-growing (pioneer) species such as $P$. falcataria, $S$. siamea, E. cyclocarpum, S. saman etc. followed by the planting of long-living tree species such as Dipterocarpaceae family, depending on the availability of the seedlings in the nursery.

Table 1 Reclamation condition from 2005-2015 in PT Mahakam Sumber Jaya

\begin{tabular}{cccc}
\hline No. & $\begin{array}{c}\text { Year of } \\
\text { planting }\end{array}$ & $\begin{array}{c}\text { Total area } \\
\text { (ha) }\end{array}$ & $\begin{array}{c}\text { Total planted } \\
\text { trees }(\mathbf{n})\end{array}$ \\
\hline 1 & 2005 & 75.39 & 61,255 \\
2 & 2006 & 33.82 & 27,479 \\
3 & 2007 & 285.18 & 316,192 \\
4 & 2008 & 152.84 & 124,182 \\
5 & 2009 & 137.47 & 111,695 \\
6 & 2010 & 199.44 & 162,045 \\
7 & 2011 & 63.94 & 51,951 \\
8 & 2012 & 323.76 & 263,055 \\
9 & 2013 & 177.08 & 132,251 \\
10 & 2014 & 162.77 & 132,251 \\
11 & 2015 & 125.14 & 101,676 \\
\hline
\end{tabular}

\subsection{Field data collection}

A vegetation inventory was used in order to understand the process of vegetation development in the reclamation area (succession). In order to make a comparison, vegetation inventories were conducted in reclamation areas of different ages and in the remaining secondary natural forest. A vegetation inventory of the one-year-old (1-yr-old) plantation (reclamation 2015) was conducted in the reclamation area of Block E; the four-year-old (4-yr-old) plantation (reclamation 2012) was conducted in the reclamation area of Block D; the six-year-old (6-yr-old) plantation (reclamation 2010) was conducted in the reclamation area of Block $D$ as well; the nine-year-old (9-yr-old) plantation (reclamation 2007) was carried out in the reclamation area of Block B and Block C, and the 11-year-old (11-yr-old) plantation (reclamation 2005) was conducted in the reclamation area of Block $A$. Whereas for the secondary natural forest a vegetation inventory was conducted in the remaining forest area (riverside) surrounding Block $D$. This remaining forest areas have been reduced in size due to illegal logging activities since then.

The vegetation inventory was performed using a modified circular plot of radius $r=17.8 \mathrm{~m}$ or about 0.1 ha (James \& Shugart 1970). A total of 10 plots (1 ha), which is the minimum plot size that can be used for silvicultural research (Lamprecht 1989), were made for each of the vegetation/stand type in the reclamation areas $(1,4,6,9$ and 11-yr-old) and for the secondary natural forest (Figure 1). Thus, the total area of reclamation and the secondary natural forest inventory was 60 plots or 6 ha. For a comprehensive and unbiased collection of data the distance between the plots was $50 \mathrm{~m}$. Meanwhile, the sampling method was carried out by using a systematic grid with a random start in order to obtain representative data and equal probability of data inclusion. The circular plot was divided into three compartments, namely compartment ' $a$ ' with a radius of $2 \mathrm{~m}$, compartment ' $b$ ' with a radius of $5 \mathrm{~m}$, and main plot or compartment ' $c$ ' with a radius of $17.8 \mathrm{~m}$. The compartment differentiation was made for counting and measuring the different stages of trees, namely: compartment ' $a$ ' was a sub-plot for calculating the seedling stage with the characteristics of a total height (h) of $30 \mathrm{~cm} \leq h \leq 1.30 \mathrm{~m}$; compartment ' $b$ ' was a sub-plot for measuring trees (sapling stage) 
that had a diameter at breast height ( $\mathrm{DBH}, 1.3 \mathrm{~m} \mathrm{~h}), 1 \mathrm{~cm} \leq \mathrm{DBH}<10 \mathrm{~cm}$; and compartment ' $\mathrm{c}$ ' was the main plot for measuring trees with a $\mathrm{DBH} \geq 10 \mathrm{~cm}$.

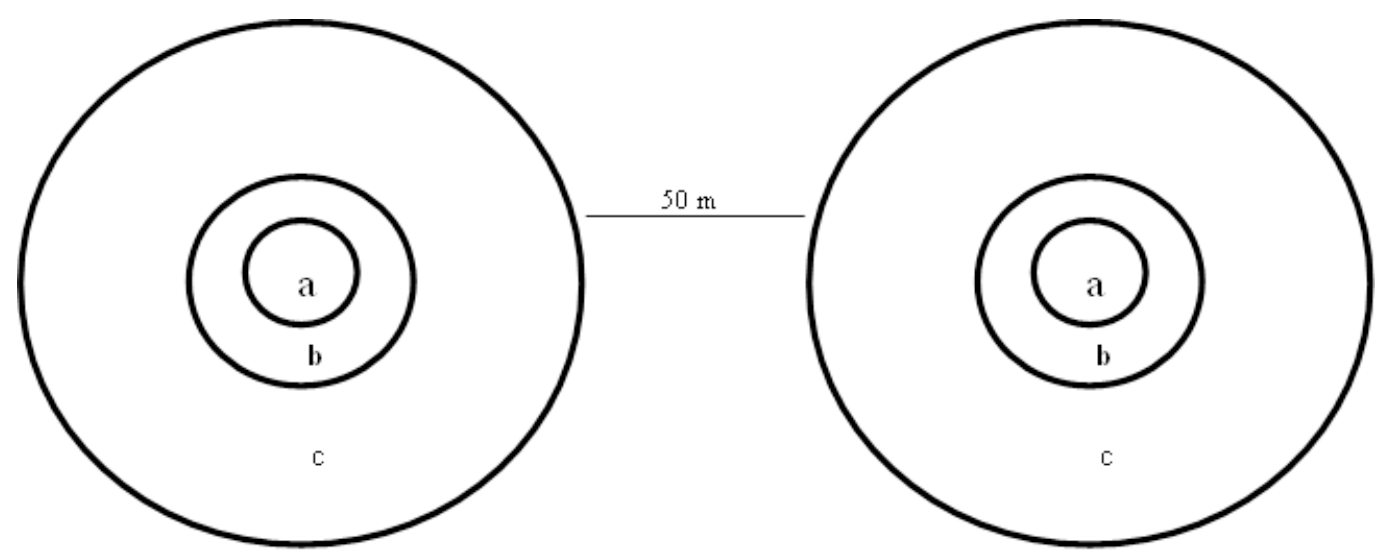

- a with radius $r=2 \mathrm{~m}$; calculating the seedling stage (total height (h) of $30 \mathrm{~cm} \leq h \leq 1.30 \mathrm{~m}$ )

- $b$ with radius $r=5 \mathrm{~m}$; measuring the sapling stage (diameter at breast height $(D B H)=1.3 \mathrm{~m} \mathrm{~h}) 1 \mathrm{~cm} \leq D B H<10 \mathrm{~cm}$

- $c$ with radius $r=17.8 \mathrm{~m}$; measuring the tree stage $(D B H=1.3 \mathrm{~m} \mathrm{~h}) \geq 10 \mathrm{~cm}$.

Figure 1 Sampling design in a vegetation inventory conducted in PT Mahakam Sumber Jaya

\section{Data}

The following parameters were recorded and measured during the vegetation inventory, i.e. species name, species number, DBH and total height in both the reclamation areas and secondary natural forest. Data recorded at the time of the vegetation inventory, were then analysed in order to understand the vegetation (stand) structure and floristic composition of reclamation areas and secondary natural forest (Table 2). Data analysed for the reclamation areas are the combination of planted trees and natural regeneration.

Table 2 Algorithms used for the measurements of vegetation structure and floristic composition (continued next page)

\begin{tabular}{|c|c|c|}
\hline Index & Algorithm & Source \\
\hline $\begin{array}{l}\text { Arithmetic mean diameter } \\
\text { (đ) }\end{array}$ & $\begin{array}{l}\qquad \overline{\mathrm{d}}=\frac{\sum_{\mathrm{i}=1}^{\mathrm{N}} \mathrm{di}}{\mathrm{N}} \\
\text { where: } \\
\mathrm{di}=\text { diameter of the individual tree } \\
\mathrm{N}=\text { total number of trees of the stand }\end{array}$ & $\begin{array}{l}\text { Curtis \& Marshal } \\
2000\end{array}$ \\
\hline $\begin{array}{l}\text { Quadratic mean diameter } \\
\text { (đg) }\end{array}$ & $\begin{array}{l}\quad \overline{\mathrm{d}} g=\sqrt{\sum_{\mathrm{i}=1}^{\mathrm{n}} \mathrm{di}^{2} / \mathrm{n}} \\
\text { where: } \\
\mathrm{di}=\text { diameter of the individual tree } \\
\mathrm{n}=\text { total number of trees of the stand }\end{array}$ & $\begin{array}{l}\text { Curtis \& Marshal } \\
2000\end{array}$ \\
\hline Total stand basal area (G) & $\begin{array}{l}\qquad=\sum_{i=1}^{\mathrm{N}} \mathrm{gi} \text {; and } \mathrm{gi}=\frac{\pi}{4} \cdot \mathrm{di}^{2} \\
\text { where: } \\
\text { gi = basal area of the } \mathrm{i}^{\text {th }} \text { trees } \\
\text { di = diameter at breast height }(\mathrm{DBH}) \text { of the trees }\end{array}$ & Laar \& Akça 2007 \\
\hline $\begin{array}{l}\text { Arithmetic mean height } \\
\left(\mathrm{h}_{\overline{\mathrm{d}}}\right)\end{array}$ & $\begin{array}{l}\qquad \mathrm{h}_{\overline{\mathrm{d}}}=\frac{\sum_{\mathrm{i}=1}^{\mathrm{N}} \mathrm{hi}}{\mathrm{N}} \\
\text { where: } \\
\text { gi = basal area of the } \mathrm{i}^{\text {th }} \text { trees } \\
\mathrm{di}=\text { DBH of the trees }\end{array}$ & Laar \& Akça 2007 \\
\hline
\end{tabular}




\begin{tabular}{|c|c|c|}
\hline Index & Algorithm & Source \\
\hline Lorey's mean height ( $\overline{\mathrm{h}} \mathrm{g}$ ) & $\begin{array}{l}\qquad \quad \bar{h} g=\frac{\sum_{\mathrm{i}=1}^{\mathrm{N}} \text { gi. hi }}{\sum_{\mathrm{i}=1}^{\mathrm{N}} \mathrm{gi}} \\
\text { where: } \\
\mathrm{hi}=\text { height of the } \mathrm{i}^{\text {th }} \text { trees } \\
\text { gi = basal area of the } \mathrm{i}^{\text {th }} \text { trees }\end{array}$ & Laar \& Akça 2007 \\
\hline Shannon Wiener Index (H') & $\begin{array}{l}\quad-\sum \text { pi ln pi } \\
\text { where: } \\
\text { pi = the proportional abundance of the } i^{\text {th }} \text { species } \\
\text { (ni/N) }\end{array}$ & Magurran 1988 \\
\hline
\end{tabular}

Further data from vegetation inventory is carried out statistical analysis to find out correlations, relationships, significant differences, similarities, dissimilarities etc. by using the software STATISTICA 13.0. The statistical analyses include One-Way ANOVA, Kruskal-Wallis ANOVA, Mann-Whitney Test, Tukey test, Cluster analysis, regression etc.

\section{$4 \quad$ Results and discussion}

\subsection{Vegetation structure}

\subsubsection{Diameter}

The mean diameter calculated was based on both arithmetic and quadratic (basal area) mean diameter formulas. Generally, the mean diameters of trees in the reclamation areas (4-yr-to 11-yr-old plantations) were greater than those of the secondary natural forest, in terms of both arithmetic mean and quadratic mean (Table 3).

Table 3 Arithmetic mean diameter and quadratic mean diameter of diameter at breast height (DBH) $\geq 10 \mathrm{~cm}$

\begin{tabular}{lccc}
\hline Stand type & N & $\begin{array}{c}\text { Arithmetic mean } \pm \\
\text { standard deviation }(\mathbf{c m})\end{array}$ & $\begin{array}{c}\text { Quadratic } \\
\text { mean }(\mathbf{c m})\end{array}$ \\
\hline Secondary natural forest* & 10 & $21.40 \pm 2.34 \mathrm{a}$ & 23.54 \\
11-yr-old plantation* & 10 & $27.05 \pm 2.72 \mathrm{~b}$ & 29.24 \\
9-yr-old plantation* & 10 & $27.74 \pm 5.03 \mathrm{~b}$ & 30.84 \\
6-yr-old plantation* & 10 & $26.42 \pm 3.17 \mathrm{~b}$ & 28.80 \\
4-yr-old plantation* & 10 & $28.42 \pm 2.83 \mathrm{~b}$ & 30.10 \\
1-yr-old plantation** & 10 & $3.49 \pm 1.95$ & 3.99 \\
\hline *-significantly different One-Way ANOVA test (p-value $=0.000199 ; \mathrm{F}=6.914763) .{ }^{* *}$ - calculated \\
from 1 cm $\leq$ DBH <10 cm.
\end{tabular}

The results show that the highest arithmetic mean diameter was present at the 4-yr-old plantation, which was $28.4 \mathrm{~cm}$; while the quadratic mean diameter of the 9-yr-old and 4-yr-old plantations were relatively similar, i.e. $30 \mathrm{~cm}$. In general, the species in the 4 -yr-old plantation were the fast-growing species E. cyclocarpum (204/ha) of the Fabaceae family. This species grows 20 to $30 \mathrm{~m}$ in height and has a trunk diameter of up to $3 \mathrm{~m}$ (Barrientos-Ramírez et al. 2015). Besides its fast-growing characteristic, many mining 
companies are planting it in order to gain a wide canopy, since the canopy is one of the main criteria for a successful mine reclamation (Figure 2(a)).

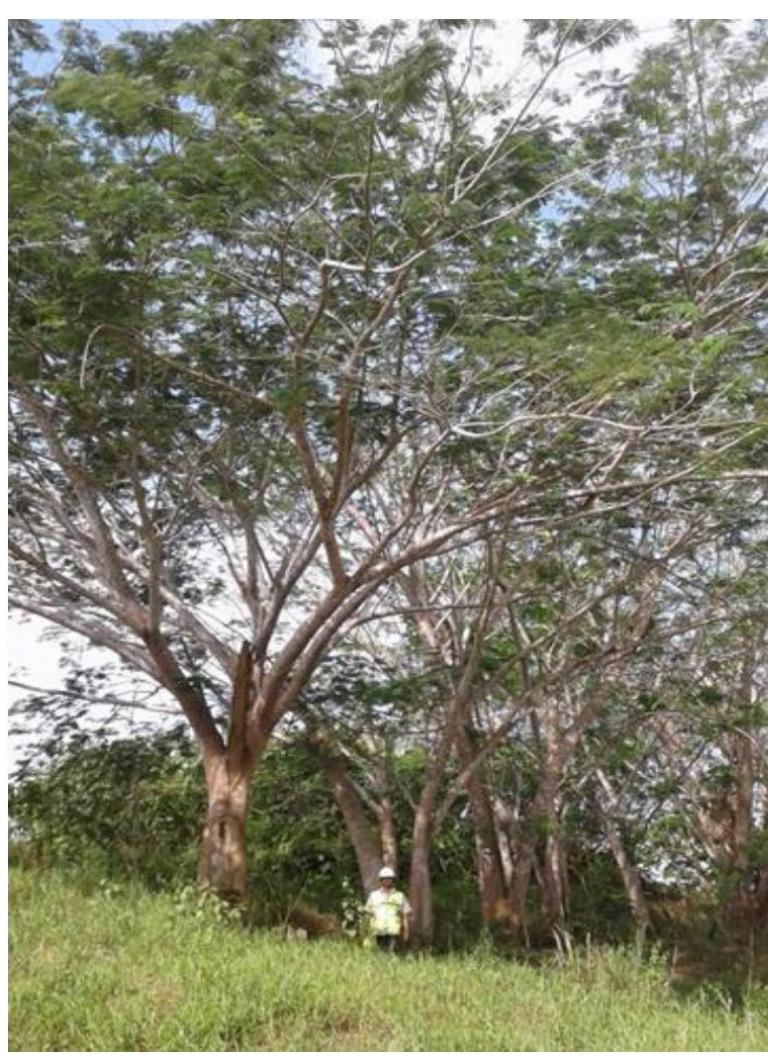

(a)

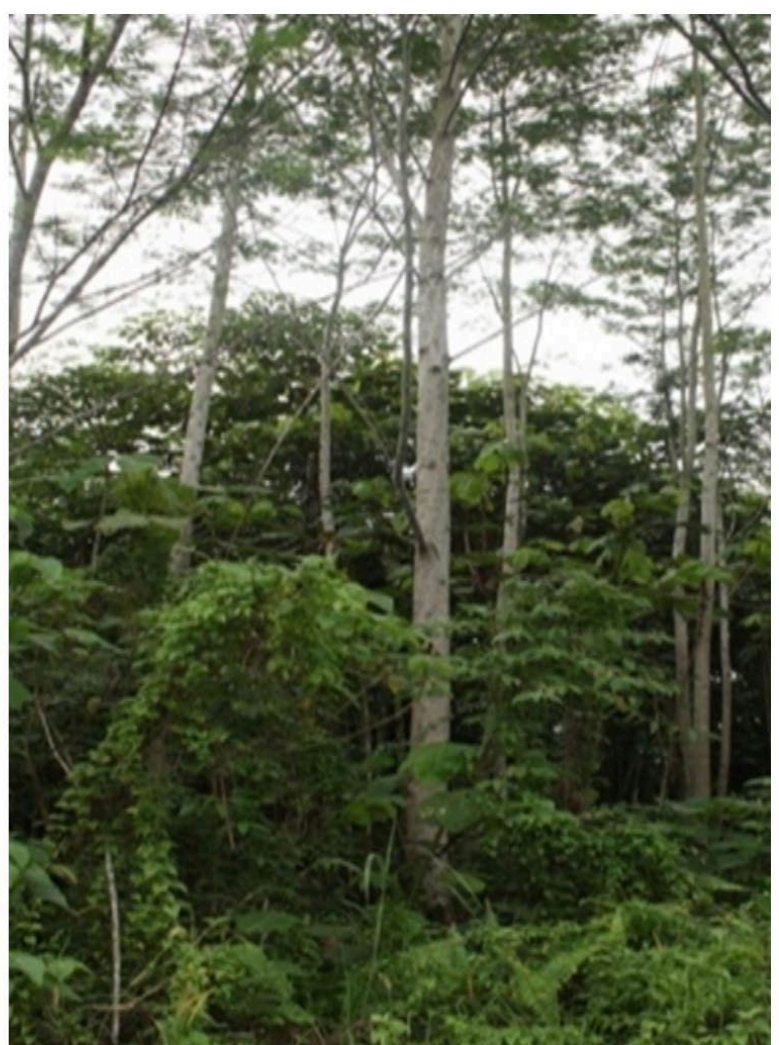

(b)

Figure 2 (a) E. cyclocarpum present at the 4-yr-old plantation; (b) P. falcataria present at 11-yr-old plantation in the research area

Based on the One-Way ANOVA analysis (1-yr-old plantation excluded), the mean diameter was significantly different to the $p$-value $=0.000199$ and $F=6.914763$. Furthermore, a post hoc analysis using the Tukey's Honest Significant Difference (Tukey HSD) test was conducted to distinguish the differences among the stand types. Apart from the 1-yr-old plantation, the mean diameter of the secondary natural forest was considerably smaller than in all reclamation ages where the mean arithmetic value did not differ significantly. This means that the diameter growth in the reclamation area was stagnant, possibly caused by a lack of nutrient supply, which is essential for plant growth. Fertilisation activities in the reclamation area are usually conducted only during the first year plantation every three months.

\subsubsection{Total height}

The mean of total height for the reclamation areas (4-yr-old to 11-yr-old plantations) and the secondary natural forest was calculated based on $\mathrm{DBH} \geq 10 \mathrm{~cm}$, while the 1-yr-old plantation was calculated based on the trees with $1 \mathrm{~cm} \leq \mathrm{DBH}<10 \mathrm{~cm}$ (Table 4). The 11-yr-old plantation had the highest mean height values (concerning the total height, the arithmetic mean and Lorey's mean height) compared to all other stand types (except the 1-yr-old plantation). Based on the One-Way ANOVA analysis, the arithmetic mean values of the total height were significantly different, while the mean values of the total height of the 9-yr-old and 11-yr-old plantations were not significantly different. 
Table 4 Mean height of the secondary natural forest and reclamation areas

\begin{tabular}{lcccc}
\hline Stand type & $\mathbf{N}$ & $\begin{array}{c}\text { Arithmetic mean } \pm \\
\text { standard deviation }(\mathbf{m})\end{array}$ & $\begin{array}{c}\text { Lorey's mean } \\
(\mathbf{h} \mathbf{g} ; \mathbf{m})\end{array}$ & $\begin{array}{c}\text { Top mean*** } \\
\left(\mathbf{h}_{\text {dom }} \mathbf{m}\right)\end{array}$ \\
\hline Secondary natural forest* & 10 & $13.99 \pm 3.99 \mathrm{a}$ & 16.39 & 19.00 \\
11-yr-old plantation* & 10 & $16.85 \pm 3.32 \mathrm{~b}$ & 18.25 & 20.86 \\
9-yr-old plantation* & 10 & $15.87 \pm 4.98 \mathrm{~b}$ & 17.91 & 23.95 \\
6-yr-old plantation* & 10 & $12.77 \pm 1.99 \mathrm{ac}$ & 13.45 & 14.59 \\
4-yr-old plantation* & 10 & $11.41 \pm 2.11 \mathrm{c}$ & 12.34 & 13.54 \\
1-yr-old plantation** & 10 & $4.11 \pm 1.81$ & 5.53 & 6.26 \\
\hline
\end{tabular}

$*$ - significantly different, One-Way ANOVA test ( $\mathrm{p}$-values $=0.000000 ; \mathrm{F}=19.37834) .{ }^{*}$ - calculated from height $(\mathrm{h}) 1.30 \mathrm{~m}$ and $1 \mathrm{~cm} \leq$ diameter at breast height $(\mathrm{DBH})<10 \mathrm{~cm}$ and calculated from 10 tallest trees. ${ }^{* * *}$ - calculated from 100 tallest trees.

In general, the older reclamation ages, for example the 9-yr-old and 11-yr-old plantations, had higher values of the total height, the arithmetic mean height, Lorey's mean height and the top mean height. This condition occurred because the planted species, namely $P$. falcataria, became one of the most dominant species in these reclamation areas (Figure 2(b)). P. falcataria is a fast-growing species that can reach heights of even $45 \mathrm{~m}$ (Kurinobu et al. 2007).

\subsubsection{Density and basal area}

The parameters of density and basal area were calculated based on the trees $\mathrm{DBH} \geq 10 \mathrm{~cm}$. However, the density and basal area of the 1-yr-old plantation was calculated from $1 \mathrm{~cm} \leq \mathrm{DBH}<10 \mathrm{~cm}$ and was not included in the One-Way ANOVA analysis (Table 5). The highest mean density was the 9-yr-old plantation (469 trees/ha). As well as the mean basal area, the 9-yr-old plantation had the highest mean value of basal area which was $35.0 \mathrm{~m}^{2} / \mathrm{ha}$. The mean density and basal area of the secondary natural forest area was 332 trees/ha and $14.5 \mathrm{~m}^{2} /$ ha, respectively. Based on the One-Way ANOVA analysis (1-yr-old plantation excluded) with a post hoc analysis of the Tukey HSD test, the parameters of mean density and mean basal area were significantly different to $p$-value $=0.001143 ; \mathrm{F}=5.456055$ and $\mathrm{p}$-value $=0.000012 ; \mathrm{F}$ value $=9.496827$, respectively. The mean density of the secondary natural forest was significantly different to the 9-yr-old plantation, but did not differ significantly to the 4-yr-old, 6-yr-old and 11-yr-old plantations. In terms of mean basal area, the secondary natural forest was significantly lower compared to all reclamation ages (1-yr-old plantation excluded).

Table 5 Mean density and basal area of diameter at breast height (DBH) $\geq 10 \mathrm{~cm}$

\begin{tabular}{lccc}
\hline Stand type & $\mathbf{n}$ & $\begin{array}{c}\text { Density } \pm \text { standard } \\
\text { deviation** }(\mathbf{n} / \mathrm{ha})\end{array}$ & $\begin{array}{c}\text { Mean basal area } \pm \text { standard } \\
\text { deviation*** }\left(\mathbf{m}^{2} / \mathrm{ha}\right)\end{array}$ \\
\hline Secondary natural forest & 10 & $332 \pm 78 \mathrm{ac}$ & $14.45 \pm 4.41 \mathrm{a}$ \\
11-yr-old plantation & 10 & $347 \pm 102 \mathrm{abc}$ & $23.29 \pm 7.23 \mathrm{~b}$ \\
9-yr-old plantation & 10 & $469 \pm 116 \mathrm{~b}$ & $35.04 \pm 11.11 \mathrm{c}$ \\
6-yr-old plantation & 10 & $394 \pm 121 \mathrm{abc}$ & $25.66 \pm 9.73 \mathrm{bc}$ \\
4-yr-old plantation & 10 & $272 \pm 70 \mathrm{c}$ & $19.35 \pm 4.69 \mathrm{~b}$ \\
1-yr-old plantation* & 10 & $382 \pm 288$ & $0.02 \pm 0.02$ \\
\hline
\end{tabular}

${ }^{*}$ - calculated from $1 \mathrm{~cm} \leq \mathrm{DBH}<10 \mathrm{~cm} ;{ }^{* *}$ - significantly different, One-Way ANOVA test ( $\mathrm{p}$-value $=0.001143$;

$F=5.456055) ;{ }^{* * *}$ - significantly different, One-Way ANOVA test ( $p$-values $\left.=0.000012 ; F=9.496827\right)$.

In general, the reclamation process in Indonesia for planting activities is carried out by two types of tree species, namely pioneer or fast-growing species and slower-growing or long-lived (under-shelter) species. 
The fast-growing species were usually planted at a spacing of $4 \times 4 \mathrm{~m}$, therefore the number per hectare was $625 \mathrm{n} / \mathrm{ha}$. Within the composition of planted trees there was a greater number of fast-growing species than slower-growing species. An increased number of slower-growing species was expected from the growth of other species natural regeneration in the reclamation area. The dominant fast-growing species planted in this mining company's reclamation area were $P$. falcataria, E. cyclocarpum and $S$. saman. The three species had a mean diameter growth of 11.3 to $18.7 \mathrm{~cm}$ (3-5 years-old), $3 \mathrm{~m}$ (old stand), $6.6 \mathrm{~cm}$ (two-year-old) and mean height 11.7 to $20.5 \mathrm{~m}$ (3-5 years-old), 20 to $30 \mathrm{~m}$ (old stand), 15-25 m (old stand), respectively (Kurinobu et al. 2007; Barrientos-Ramírez et al. 2015; Sowjanya et al. 2014). Moreover, Roberts et al. (2015) found that the growth of height and diameter of tree species grown in the reclamation area was higher than that of natural forests. It shows that the growth of planted pioneer species on mine reclamation area is relatively similar or even greater than the other area (non-mine reclamation area).

\subsection{Floristic composition}

\subsubsection{Diversity index}

In general, the oldest reclamation ages (6-yr-old, 9-yr-old and 11-yr-old) had greater number of the species (natural regeneration) found than the youngest reclamation ages (1-yr-old and 4-yr-old) (Figure 3). This shows that the increment of reclamation age creates a good environmental condition to support the natural regeneration and growth of further species (Parrotta et al. 1997).

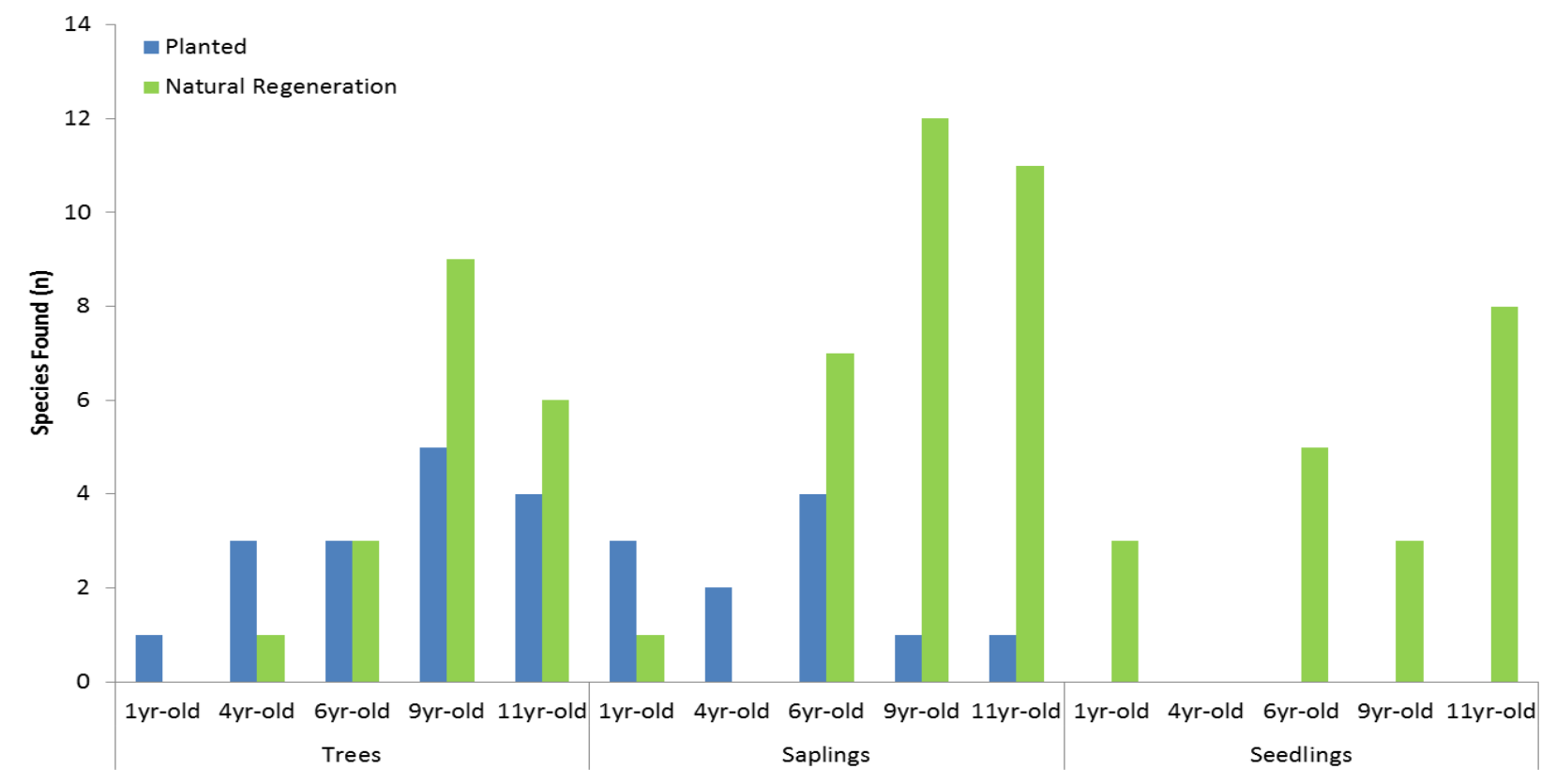

Figure 3 Number of species found in the reclamation areas both planted and natural regeneration

In general, the youngest (1-yr-old and 4-yr-old) plantations had the lowest numbers of species (total of planted and natural regeneration species) amongst the reclamation areas for all stages (seedling, sapling and tree). This occurred because of the high mortality rate and the limited amount of natural regeneration in the 1-yr-old plantation (open area, directly exposed to sunlight) and in the 4-yr-old plantation (livestock grazing activities (buffalo) by surrounding communities).

Based on the results of statistical analysis, the mean of diversity index (Shannon Wiener $\left(H^{\prime}\right)$ ) of the tree stage was significantly different (Table 6). The secondary natural forest had the highest mean value of diversity indices (species number $(\mathrm{n})$ and $\mathrm{H}^{\prime}$ ) in comparison to all reclamation ages, while the 1-yr-old plantation had the lowest mean of diversity indices, i.e. zero (one species found). According to the Mann-Whitney U Test, the mean of $\mathrm{H}^{\prime}$ index of the secondary natural forest was significantly different in comparison to all reclamation ages (the same letters after the values imply that they are not significantly different). In general, the $\mathrm{H}^{\prime}$ index was not significantly different in the 4-yr-old to 11-yr-old plantations. This means that the species 
diversity (species number) in the 4-yr-old to 11-yr-old plantations did not increase significantly. The limited number of natural regeneration tree species may have been caused by the high clay content found in the reclamation area, whereby the roots of the plants could not penetrate the soil, therefore competition increased.

Table 6 Species number $(n)$ and Shannon Wiener $\left(H^{\prime}\right)$ index of the tree, sapling and seedling stages

\begin{tabular}{|c|c|c|c|c|c|c|}
\hline \multirow[b]{2}{*}{ Stand type } & \multicolumn{2}{|r|}{ Trees } & \multicolumn{2}{|r|}{ Sapling } & \multicolumn{2}{|r|}{ Seedling } \\
\hline & $\begin{array}{c}\text { Species } \\
\text { (n) }\end{array}$ & $\begin{array}{c}\text { Shannon Wiener } \\
\text { Index* }\left(\mathrm{H}^{\prime}\right)\end{array}$ & $\begin{array}{l}\text { Species } \\
\text { (n) }\end{array}$ & $\begin{array}{c}\text { Shannon Wiener } \\
\text { Index* }\left(\mathbf{H}^{\prime}\right)\end{array}$ & $\begin{array}{c}\text { Species } \\
\text { (n) }\end{array}$ & $\begin{array}{c}\text { Shannon Wiener } \\
\text { Index* }\left(H^{\prime}\right)\end{array}$ \\
\hline $\begin{array}{l}\text { Secondary } \\
\text { natural forest }\end{array}$ & 67 & $3.48 a$ & 50 & $2.95 a$ & 34 & $2.75 a$ \\
\hline $\begin{array}{l}\text { 11-yr-old } \\
\text { plantation }\end{array}$ & 10 & $1.16 \mathrm{~b}$ & 12 & $1.32 b$ & 8 & $1.82 \mathrm{~b}$ \\
\hline $\begin{array}{l}\text { 9-yr-old } \\
\text { plantation }\end{array}$ & 14 & $1.52 b$ & 13 & $1.27 b$ & 3 & $0.42 c$ \\
\hline $\begin{array}{l}\text { 6-yr-old } \\
\text { plantation }\end{array}$ & 6 & $1.15 b$ & 11 & $2.17 b c$ & 5 & $1.30 \mathrm{bc}$ \\
\hline $\begin{array}{l}\text { 4-yr-old } \\
\text { plantation }\end{array}$ & 4 & $0.77 b$ & 2 & $0.69 d$ & 0 & $0.00 c$ \\
\hline $\begin{array}{l}\text { 1-yr-old } \\
\text { plantation* }\end{array}$ & 1 & $0.00 c$ & 4 & $1.35 \mathrm{~cd}$ & 3 & $0.57 b c$ \\
\hline
\end{tabular}

* - significantly different, Kruskal-Wallis ANOVA test and compared among stand types using the Mann-Whitney U Test: $\mathrm{H}^{\prime}(\mathrm{p}$-value = 0.0000$)$;

$J^{\prime}(p$-value $=0.0000) ; 1-D(p-$ value $=0.0000)$.

In the sapling stage, the secondary natural forest had the highest mean values of $\mathrm{H}^{\prime}$ index compared to all reclamation ages. The results of statistical analysis (Table 6) show that mean values of $H^{\prime}$ index for the sapling stages were significantly different. Similar to the tree stage, the mean values of $\mathrm{H}^{\prime}$ index of the secondary natural forest were significantly different compared to all reclamation ages. The 6-yr-old to 11 -yr-old plantations show no significant difference regarding the $\mathrm{H}^{\prime}$ index. This means that the species diversity (species number) in the 6-yr-old to 11 -yr-old plantations does not increase significantly. A similar problem also appears in the tree stage. As already mentioned for the tree stage the limited number of natural regeneration tree species was probably caused by the high clay content found in the reclamation area.

The statistical analysis results showed that the mean values of $\mathrm{H}^{\prime}$ index at the seedling stage did also differ significantly. The secondary natural forest had the highest number of $\mathrm{H}^{\prime}$ index at sub-plot level, i.e. 2.75 (Table 6). Among the reclamation ages, the 11-yr-old plantation had the highest mean values of $\mathrm{H}^{\prime}$ index, while the lowest mean value of $\mathrm{H}^{\prime}$ index was taken in the 4-yr-old plantation (reclamation 2012), i.e. zero (0). In general, the diversity indices (species number $(n)$ and $H^{\prime}$ ) of the 1-yr-old to 9-yr-old plantations show no significant difference. The $\mathrm{H}^{\prime}$ index in the seedling stage fluctuate alongside the increasing age of reclamation. Besides of the high clay content, the $\mathrm{H}^{\prime}$ index for each age of reclamation are influenced by several factors that occur in the area. For example, in the 9-yr-old plantation the diversity was small due to the illegal planting of Hevea brasiliensis (rubber) trees, whereas the small value of $\mathrm{H}^{\prime}$ index in the 4-yr-old plantation was caused by livestock grazing in the surrounding habitat.

\subsubsection{Cluster analysis}

The data used for cluster analysis were the number of species and the Shannon Wiener $\left(\mathrm{H}^{\prime}\right)$, Shannon Evenness (J') and Simpson (1-D) indices of seedling, sapling and tree stages. Looking at the cluster analysis in Figure 4, it appears that it forms three main groups: the first clusters were formed by the reclamation areas of 1-yr-old and 4-yr-old plantations; the second clusters were formed by the reclamation areas of 6-yr-old, 
9-yr-old and 11-yr-old plantations; and the third main clusters were formed by all reclamation areas compared to the secondary natural forests. The lowest dissimilarity distance was recorded between the 1 -yr-old plantation and the 4-yr-old plantation, namely $4.92 \%$. While the highest dissimilarity distance was recorded between the 1-yr-old plantation and the secondary natural forest, i.e. $86.34 \%$. Among the reclamation ages, the 9 -yr-old plantation had the lowest dissimilarity distance with the secondary natural forest, which was $71.78 \%$ or $28.22 \%$ of similarity. The low number of natural regeneration species (tree, sapling and seedling) in the reclamation area led to a high dissimilarity distance with the secondary natural forest.

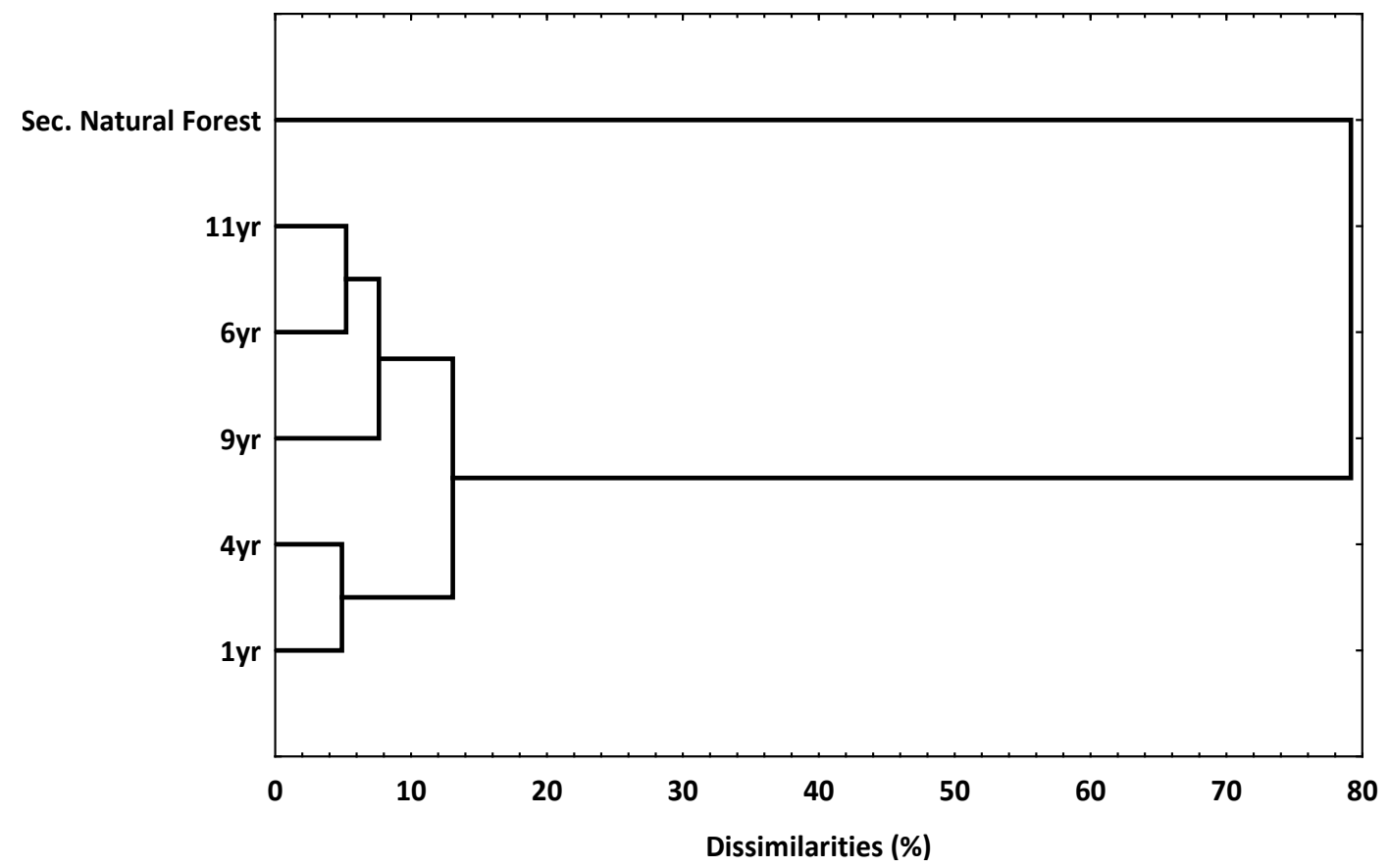

Figure 4 Cluster analysis from the number of species and diversity indices of the secondary natural forest (Sec. Natural Forest) with reclamation areas (1 yr, 4 yr, 6 yr, 9 yr and $11 \mathrm{yr}$ )

\subsection{Natural regeneration}

In the seedling stage, there were altogether 16 species of 11 families that grew naturally in the reclamation area. The highest number of seedlings in the seedling stage was from the species Bridelia glauca (Phyllanthaceae) (875/ha; Table 7).

Table $7 \quad$ Number of natural regeneration species found at seedling stage (continued next page)

\begin{tabular}{cllc}
\hline No & Species Name* & Family & Abundance (n/ha) \\
\hline 1 & Bridelia glauca & Phyllanthaceae & 875 \\
2 & Trema orientalis & Ulmaceae & 795 \\
3 & Monocarpia euneura & Annonaceae & 636 \\
4 & Macaranga tanarius & Euphorbiaceae & 478 \\
5 & Ficus obscura & Moraceae & 318 \\
6 & Vitex pinnata & Verbenaceae & 318 \\
7 & Polyalthia sumatrana & Annonaceae & 239 \\
8 & Mezzetia parviflora & Annonaceae & 202 \\
9 & Glochidion calospermum & Phyllantaceae & 159 \\
\hline
\end{tabular}




\begin{tabular}{lllc}
\hline No & Species Name* & Family & Abundance (n/ha) \\
\hline 10 & Actinodaphne glabra & Lauraceae & 80 \\
11 & Anthocephalus cadamba & Rubiceae & 80 \\
12 & Dillenia reticulate & Dilleniaceae & 80 \\
13 & Drypetes longifolia & Putranjivaceae & 80 \\
14 & Geunsia pentandra & Lamiaceae & 80 \\
15 & Macaranga trichocarpa & Euphorbiaceae & 80 \\
16 & Neonauclea excels & Rubiaceae & 80 \\
\hline
\end{tabular}

The total numbers of natural regeneration species found in the sapling stage in the reclamation area were 24 species of 13 families (Table 8), which is considerably more than in the seedling stage. Mezzetia parviflora (Annonaceae) displayed the highest number of individuals $(1,833 / \mathrm{ha})$.

Table 8 Number of natural regeneration species found at sapling stage

\begin{tabular}{cllc}
\hline No & Species Name* & Family & Abundance (n/ha) \\
\hline 1 & Mezzetia parviflora & Annonaceae & 1,833 \\
2 & Monocarpia euneura & Annonaceae & 675 \\
3 & Xanthophyllum spp. & Polygalaceae & 127 \\
4 & Trema orientalis & Ulmaceae & 115 \\
5 & Macaranga tanarius & Euphorbiaceae & 102 \\
6 & Ficus obscura & Moraceae & 77 \\
7 & Macaranga gigantean & Euphorbiaceae & 64 \\
8 & Glochidion calospermum & Phyllantaceae & 51 \\
9 & Ficus albipila & Moraceae & 26 \\
10 & Actinodaphne glabra & Lauraceae & 25 \\
11 & Anthocephalus cadamba & Rubiceae & 25 \\
12 & Dillenia reticulate & Dilleniaceae & 25 \\
13 & Neonauclea excels & Rubiaceae & 25 \\
14 & Palaquium rostratum & Sapotaceae & 25 \\
15 & Pterospermum javanicum & Sterculiaceae & 25 \\
16 & Baccaurea stipulata & Phyllanthaceae & 13 \\
17 & Cananga ordorata & Annonaceae & 13 \\
18 & Clerodendrum spp. & Lamiaceae & 13 \\
19 & Cratoxylum sumatranum & Lauraceae & 13 \\
20 & Leucaena leucocephala & Fabaceae & 13 \\
21 & Macaranga trichocarpa & Euphorbiaceae & 13 \\
22 & Nauclea subdita & Rubiaceae & 13 \\
23 & Nothaphoebe spp. & Lauraceae & 13 \\
24 & Polyalthia sumatrana & Annonaceae & 13 \\
\hline$*$ natural regeneration (native). & & \\
& & &
\end{tabular}


The all-over number of natural regeneration species in the reclaimed ex-mining area during the tree stage was 15 species of 12 families (Table 9), which is considerabley lower, compared to the all-over number of species and families found in the sapling stage. Anthocephalus cadamba (Rubiaceae) displayed the highest number of individuals (32 trees/ha), followed by Macaranga gigantea and Macaranga tanarius (Euphorbiaceae) (25 and 15 trees/ha, respectively).

Table 9 Number of natural regeneration species found at tree stage

\begin{tabular}{cllc}
\hline No & Species Name* & Family & Abundance (n/ha) \\
\hline 1 & Anthocephalus cadamba* & Rubiceae & 32 \\
2 & Macaranga gigantea* & Euphorbiaceae & 25 \\
3 & Macaranga tanarius* & Euphorbiaceae & 15 \\
4 & Mezzetia parviflora* & Annonaceae & 10 \\
5 & Pterospermum & Sterculiaceae & 10 \\
6 & Gliricidia sepium* & Fabaceae & 5 \\
7 & Dillenia indica* & Dilleniaceae & 2 \\
8 & Monocarpia euneura* & Annonaceae & 2 \\
9 & Acacia mangium** & Fabaceae & 1 \\
10 & Actinodaphne glabra* & Lauraceae & 1 \\
11 & Alstonia scholaris* & Apocynaceae & 1 \\
12 & Ficus obscura* & Moraceae & 1 \\
13 & Glochidion calospermum* & Phyllantaceae & 1 \\
14 & Trema orientalis* & Ulmaceae & 1 \\
15 & Vernonia arborea* & Asteraceae & 1 \\
\hline$*-$ natural regeneration (native)**-natural regeneration (exotic). & \\
& & &
\end{tabular}

\subsection{Species number and reclamation age}

The relationship between the numbers of species and the increasing age of reclamation was calculated using a simple polynomial regression analysis and the software STATISTICA 13.0. The statistical analysis was based on the ten plots of the vegetation inventory.

The results show a significant relationship between the number $(n)$ of species and the rise in reclamation age. The tree stage had $r^{2}=0.60$ and $p$-value $=0.000000$, which is the highest value compared to $r^{2}$ in the sapling and seedling stages. The sapling stage had $r^{2}=0.45$ and $p$-value $=0.000001$, while the seedling stage had $r^{2}=0.26$ and $p$-value $=0.000863$. The number of species in the tree stage tends to decrease, while the number of species in the sapling and seedling stages tends to increase simultaneously with the rise in reclamation age. The reduction in the number of species in the tree stage may be caused by root and space competition, which ultimately led to a high mortality rate.

The regression analysis between the number of species and the reclamation ages displayed a positive relationship in all growth stages (Figure 5). This indicates that the environmental condition of the reclamation area supports other species to grow. Reclamation activities in Indonesia are carried out by planting a legume cover crop, fast-growing tree species, and long-living, under-shelter tree species 2-3 years after the plantation of fast-growing tree species. The aim of planting fast-growing and under-shelter tree species is to create an appropriate microclimate for other species to regenerate and grow naturally in the reclaimed areas 
(Grant \& Koch 2007). Furthermore, the plantation of a legume cover crop in the reclamation area is strongly recommended for the initial step of land stabilisation of the ex-mining area, given its ability to increase the amount of nitrogen in the soil. In the end, the area of the reclamation process shall be sustainable and have the ability to grow into a forest with a high level of diversity.

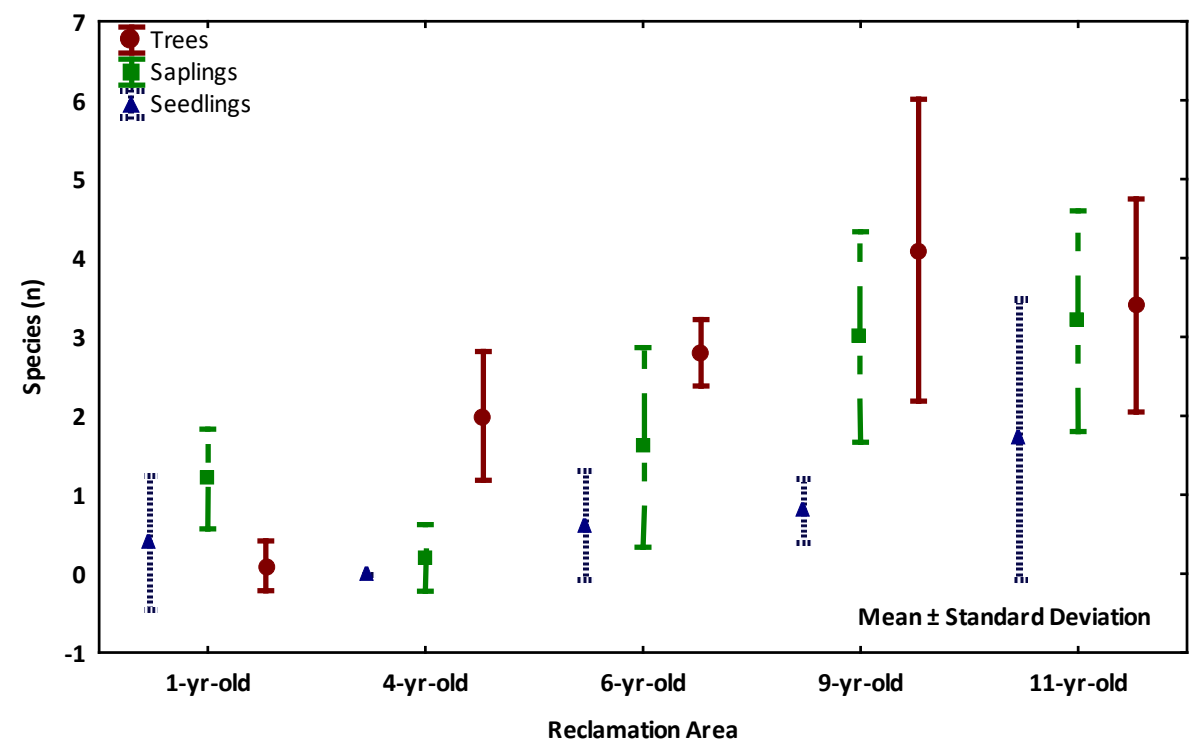

$n$ Tree: $r^{2}=0.60$ and $p$-value $=0.000000 ; n$ Sapling: $r^{2}=0.45$ and $p$-value $=0.000001 ; n$ Seedling: $r^{2}=0.26 ; p$-value $=0.000863$

Figure 5 Relationship of number of species with reclamation age

The plantation of a diverse species creates a favourable condition for a self-sustaining forest (Parrotta \& Knowles 1999) and improves the ecological conditions of the reclamation area (Rodrigues et al. 2004). In addition, the planting of native species can increase the diversity of native understory species (Parrotta et al. 1997; Koch 2007). As the reclamation site increases in age, the former mining area can be ecologically restored into a self-sustaining forest (Holl 2002).

\section{Conclusion}

The vegetation development of the stand structure in mine reclamation area shows that the distinct data for different ages of reclamation. The growth of diameter (DBH) and total height tend to increase due to the ages of reclamation increment. The planted species (pioneer species) influence the growth rate of DBH and total height, whereas the density and mean basal area are determined by the mortality rate, as well as the planted species. Similar to stand structure, the floristic composition both for number of species and Shannon Wiener index $\left(\mathrm{H}^{\prime}\right)$ tend to increase alongside with reclamation ages increment. The natural regeneration has been found from the one-year-reclamation plantation and the enhancement of natural regeneration species tends to increase by the reclamation ages increment. Thus, it appears that the reclamation activities in exmine areas have succeeded in creating favourable environmental conditions for natural regeneration.

\section{Acknowledgement}

The study was financed by the Erasmus Mundus Experts-Sustain scholarship, for which the authors are very grateful. The authors would like to acknowledge the Erasmus Mundus Action 2 programme for financing the cost of travel to Indonesia.

The authors are very grateful to the following persons for their kind support and understanding during the study: Mr M Hendrasto, MSc, Dr Lana Saria and Ms Farisatul Amanah (Ministry of Energy and Mineral Resources); Mr Didied Sulistiyono, Mr Boorliant Satriyana, Mr Simson, Mr Aditya Wibowo, Mr Arif Swastiko, Mr Rindra Prihutama and Mrs Andy Wahyunengsi (PT Mahakam Sumber Jaya); and Prof Iskandar Z Siregar and Mr Asep Mulyadiana from Bogor Agricultural University (IPB). 


\section{References}

Barrientos-Ramírez, L, Vargas-Radillo, JJ, Segura-Nieto, M, Manriquez-Gonzalez, R \& Toral, FA 2015, 'Nutritional evaluation of mature seeds of Enterolobium cyclocarpum (parota) from diverse ecological zones in Western Mexico', BOSQUE, vol. 36 no. 1, pp. 95-103.

Curtis, RO \& Marshall, DD 2000, 'Why quadratic mean diameter?', Western Journal of Applied Forestry, vol. 15, no. 3, pp. 137-139.

Doupé, RG \& Lymbery, AJ 2005, 'Environmental risks associated with beneficial end uses of mine lakes in southwestern Australia', Mine Water and the Environment, vol. 24, pp. 134-138.

Environmental Law Alliance Worldwide 2010, Guidebook for Evaluating Mining Projects ElAs, 1st edition, Environmental Law Alliance Worldwide, Eugene, Oregon.

Grant, C \& Koch, J 2007, 'Decommissioning Western Australia's first bauxite mine: co-evolving vegetation restoration techniques and targets', Ecological Management \& Restoration, vol. 8, no. 2, pp. 92-105.

Heras, MM, Nicolau, JM \& Espigares, T 2008, 'Vegetation succession in reclaimed coal-mining slopes in a Mediterranean-dry environment', Ecological Engineering, vol. 34, pp. 168-178.

Holl, KD 2002, 'Long-term vegetation recovery on reclaimed coal surface mines in the Eastern USA', Journal of Applied Ecology, vol. 39 , pp. 960-970.

James, FC \& Shugart, HH 1970, 'A quantitive method of habitat description', Audubon Field Notes National, vol. 24, pp. 727-736.

Koch, JM 2007, 'Restoring a jarrah forest understorey vegetation after bauxite mining in Western Australia?', Restoration Ecology, vol. 15 , iss. s4, pp. $26-39$.

Kurinobu, S, Prehatin, D, Mohammad, N, Matsune, K \& Chigira, O 2007, 'A provisional growth model with a size-density relationship for a plantation of Paraserianthes falcataria derived from measurements taken over 2 years in Pare, Indonesia', Journal of Forest Research, vol. 12, pp. 230-236.

Laar, A \& Akça, A 2007, Forest Mensuration, Springer, Dordrecht.

Lamprecht, H 1989, Silviculture in the Tropics, Deutsche Gesellschaft für Technische Zusammenarbeit, Eschborn, Rossdorf.

Lloyd, MV, Doherty, MD, Jeffree, RA, John, J, Majer, JD, Osborne, JM \& Nichols, OG 2002, Managing the Impacts of the Australian Minerals Industry on Biodiversity, Australian Centre for Mining Environmental, London.

Magurran, AA 1988, Ecological Diversity and Its Measurement, Springer, Dordrecht.

Martin, J \& Gower, T 1996, 'Forest succession', Forestry Facts, no. 78, pp. 78-81.

Parrotta, JA \& Knowles, OH 1999, 'Restoration of tropical moist forest on bauxite-mined lands in the Brazilian Amazon', Restoration Ecology, vol. 7, no. 2, pp. 103-116.

Parrotta, JA, Knowles, OH \& Wunderle Jr, JM 1997, 'Development of floristic diversity in 10-year-old restoration forests on a bauxite mined site in Amazonia', Forestry Ecology and Management, no. 99, pp. 21-42.

Roberts, M, Richter, J, Martin, B, Peterson, C, Le, T, Wiener, M \& Dockery, S 2015, 'Evaluating tree growth and soil development on restored coal mine sites in Eastern Kentucky', American Chestnut Restoration.

Rodrigues, RR, Martins, SV \& Barros, LC 2004, 'Tropical Rain Forest regeneration in an area degraded by mining in Mato Grosso State, Brazil', Forest Ecology and Management, vol. 190, pp. 323-333.

Sowjanya, J, Kumar, SD, Satheeshkumar, PJ, Sneha, G, Kumar, N \& Bhanuchander 2014, 'An overview on the biological perspective of Samanea saman (Jacq) Merr (rain tree)', International Journal of Pharmacy and Pharmaceutical Science, vol. 6, no. 5, pp. 8-10.

Subowo, G 2011, 'Penambangan sistem terbuka ramah lingkungan dan upaya reklamasi pascatambang untuk memperbaiki kualitas sumberdaya lahan dan hayati tanah', Jurnal Sumberdaya Lahan, vol. 5, no. 2, pp. 83-94, in Indonesian. 